\title{
Fastlegen som livsstilsveileder
}

\author{
Det er viktig at leger er bevisst på makt og avmakt \\ i lege-pasient-forholdet når de skal veilede pasienter om livsstil.
}

Sykdom som kan relateres til livsstil og usunne levevaner er en økende belastning for de som blir syke, for samfunnet og for helsetjenesten. En viktig oppgave for fastlegene er å veilede og påvirke sine pasienter til å etablere sunne levevaner.

- Fastlegene ser på dette som en viktig, men vanskelig oppgave. Generelle råd passer ikke for alle. Legen kan møte motstand hos pasientene og må forhandle om løsninger, sier Eirik Abildsnes.

Han har undersøkt holdninger, handlinger og refleksjoner hos fastleger som skal veilede pasienter til å endre livsstil. Utgangspunktet for studiene var fokusgrupper der erfarne fastleger, leger i spesialisering og turnusleger deltok.

- Mål for studiene var å undersøke hvilke kommunikasjonsverktøy fastlegene bruker i disse prosessene, analysere «makt og avmakt» $\mathrm{i}$ forholdet mellom pasienten og legen - med bakgrunn i diskusjonene i fokusgruppene - og å analysere interaksjoner mellom legene når de la frem og diskuterte egne konsultasjoner, sier Abildsnes.

Legene brukte ulike fremgangsmåter for å få pasienter til å endre livsstil: De etablerte lege-pasient-forhold bygd på samarbeid om beslutninger, de ga råd og tips for å få pasientene til å endre livsstil, men de brukte også mer paternalistiske tilnærminger og manipulerende retorikk. Presentasjon av konsultasjoner med egne pasienter kan fremme pasientens perspektiv, fremme legens refleksjoner om sin rolle og om medisinsk etikk.

- Det er viktig at legene er klar over at en «røff» kommunikasjonsform overfor pasienten for å få dem til å endre livsstil også kan ha negative effekter. Bevissthet om hvordan makt kan påvirke lege-pasient-forholdet kan gjøre livsstilsveiledning bedre og redusere risiko for skade, sier han.

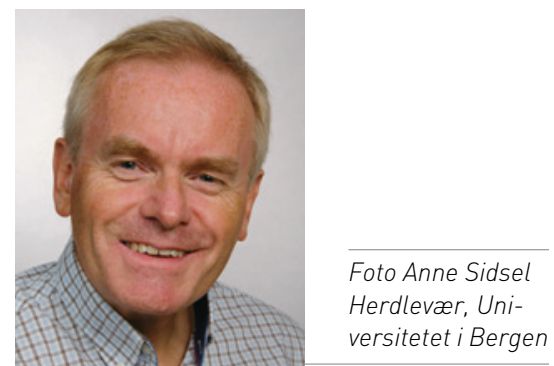

Disputas

Eirik Abildsnes disputerte for ph.d-graden ved Universitetet i Bergen 23.11. 2012. Tittel på avhandlingen er The general practitioner as lifestyle advisor. A focus group study exploring case story discussions.

\section{Relevant informasjon til forskningsdeltakere}

\author{
Norske pasientinformasjonsskriv er blitt mer omfattende de siste årene. \\ En ny studie viser at innholdet i skrivene ofte ikke er tilpasset pasientene.
}

Pasientinformasjonsskriv om kliniske studier er regulert av internasjonale retningslinjer, og krav til innhold er omfattende og skal være i pasientenes interesse. Likevel er det tenkelig at mye av innholdet ikke er til nytte for leserne.

- Man kan spørre seg om skriv som etterfølger alle kravene blir så kompliserte at det blir vanskelig for leserne å sortere ut hovedbudskapet, sier Kari Sand. Ved å intervjue lungekreftpasienter fant vi at pasientene var mest opptatt av praktisk informasjon om sin egen sykdom og behandling, og at kontekstuelle aspekter ved lesesituasjonen gjorde skrivene vanskelig å forstå.

Det ble foretatt to analyser av norske informasjonsskriv godkjent i perioden $1987-$ 2007. Resultatene viste at antall ord var tredoblet i løpet av perioden og at antall innholdselementer var fordoblet. I en oppfølgingsstudie ble også de ti eldste og ti nyeste skrivene analysert med en språkvitenskapelig tilnærming. Denne viste at nye, lengre skriv ikke nødvendigvis var mindre lesbare og funksjonelle enn de korte og eldre skrivene. Blant annet var de nye skrivene mer rettet mot tekstens hovedtema, forskning og hovedformål; å spørre leseren om han/hun er villig til å delta. Eldre skriv var mer orientert mot sykdom og behandling.

For å gi et reelt samtykke til studie må pasienten forstå informasjonen som gis. $-\mathrm{Vi}$ utførte en litteraturstudie av begrepet forståelse. Her fant vi at studier på feltet ikke er basert på en felles definisjon av forståelse, at målemetodene er utviklet for hver enkelt studie og at metodene er forskjellige med tanke på antall spørsmål og innholdet de dekker. Dermed blir det vanskelig å sammenlikne tidligere studier for å finne ut hva som kjennetegner effektiv informasjon til pasienten, avslutter Sand.

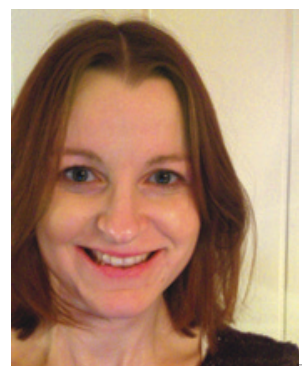

Kari Sand

Foto privat

Disputas

Kari Sand disputerte for ph.d.-graden ved Norges teknisk-naturvitenskapelige universitet 16.11. 2012. Tittelen på avhandlingen er Informed consent documents for cancer research: Textual and contextual factors of relevance for understanding. 